\title{
POPULASI Rhizophora apiculata BI DI HUTAN MANGROVE TELUK BUO PADANG SUMATERA BARAT
}

\author{
Wiwi Yulia ${ }^{1}$ \& Irma Leilani ${ }^{2}$ \\ ${ }^{1}$ Guru Biologi SMAN 11 Padang Sumatera Barat \\ ${ }^{2}$ Jurusan Biologi Universitas Negeri Padang
}

Coreponding Author:

wiwiyulia0911@gmail.com

\begin{abstract}
ABSTRAK
Ekosistem mangrove merupakan tipe ekosistem yang khas dan terdapat di sepanjang pantai atau muara sungai yang di pengaruhi oleh pasang surut air laut. Salah satu Vegetasi penyusun hutan mangrove adalah tumbuhan bakau (Rhizophora spp.). Berdasarkan hal tersebut telah dilakukan penelitian yang bertujuan untuk mengetahui struktur populasi dari Rhizophora apiculata BI di hutan mangrove Teluk Buo Kecamatan Bungus Teluk Kabung Kota Padang. Penelitian ini dilakukan dengan metode jalur dengan cara membuat plot-plot berukuran 10x10m untuk tingkat pohon, $5 \times 5 \mathrm{~m}$ untuk tingkat anakan, dan 1x1 untuk tingkat semai. Plot - plot tersebut digunakan untuk mengetahui kerapatan dan dominansi Rhizophora apiculata. Dari hasil penelitian yang telah dilakukan diketahui hasil kerapatan tertinggi $2,133 \mathrm{ind} / \mathrm{m}^{2}$ pada semai, selanjutnya $0,773 \mathrm{ind} / \mathrm{m}^{2}$ pada anakan, dan $0,161 \mathrm{ind} / \mathrm{m}^{2}$ pada pohon. Selanjutnya pada dominansi diketahui hasil tertinggi $0.000593 \mathrm{~m}^{2}$ pada anakan, $0,000381 \mathrm{~m}^{2}$ pada pohon, dan $0,0000943 \mathrm{~m}^{2}$ pada semai. Dari hasil tersebut dapat disimpulkan bahwa populasi Rhizophora apiculata yang terdapat di hutan mangrove Taluak Buo sedang mengalami regenerasi yang cukup bagus dan tergolong ke dalam hutan yang masih muda
\end{abstract}

Key Words: Ekosistem mangrove, Populasi. Rhizophora apiculata

\section{PENDAHULUAN}

Ekosistem mangrove adalah tipe ekosistem yang khas terdapat di sepanjang pantai atau muara sungai yang dipengaruhi oleh pasang surut air laut. Mangrove tumbuh disepanjang pantai yang terlindung atau pantai yang datar. Hutan mangrove biasanya berada di sepanjang sisi pulau yang terlindung dari angin atau di belakang terumbu karang di lepas pantai. Ekosistem mangrove merupakan ekosistem peralihan antara laut, dan sudah sejak lama diketahui mempunyai peranan penting dalam kehidupan (Abdullah,1984). Hutan mangrove memiliki fungsi yang sangat banyak, baik itu dari segi ekonomis, penyedia kayu bakar, obatobatan, dan juga sebagai mata pencarian karena banyaknya biota-biota laut yang hidup dan berkembang di hutan mangrove tersebut. Sedangkan dari segi ekologis mangrove memiliki fungsi sebagai penahan intrusi air laut dan menghambat limbah yang ada (Tarigan. 2008).

Vegetasi penyusun hutan mangrove yang ada di Indonesia tergabung dalam 47 jenis tumbuhan tersebar di seluruh wilayah Indonesia. Umumnya pada vegetasi ini terdapat salah satu jenis tumbuhan sejati atau dominan yang termasuk dalam empat familia yaitu 
Rhizophorceae (Rhizophora, Bruguiera dan Ceriop), Sonnerataceae (Sonneratia), Avicenniaceae (Avicennia), dan Meliaceae (Xylocarpus) (Dahuri, 2003). Rhizophoraceae terdiri dari 18 Genera dan 142 species (theplantlist, 2013). Kelompok tumbuhan ini memiliki ciri akar yang termodifikasi sebagai penunjang berdiri kokohnya batang, salah satu speciesnya ialah Rhizopora apiculata yang memiliki akar penunjang batang mulai dari pangkal batang, bahkan terkadang sampai kecabang bagian atasnya. Tumbuhan ini memiliki kemiripan bentuk propagul dengan genus Bruguiera seperti pada species Bruguiera cylindrica, namun $B$. cylindria (L.) Blume memiliki tipe akar lutut yang melebar dibagian pangkal batang dengan warna akar coklat tua, kecoklatan berbintik kuning; warna batang utama putih keabu-abuan; warna cabang tua kecoklatan (Rizki, Safitri \& Asroen, 2015).

Tumbuhan bakau memiliki peranan penting dalam menjaga keberlangsungan ekosistem pantai, mampu menahan abrasi, pengikisan oleh aliran air dari daratan, bahkan mampu meredam hempasan tsunami. Selain itu tumbuhan mangrove seperti $R$. apiculata memiliki peranan sebagai tumbuhan yang dapat menyembuhkan berbagai penyakit. Masyarakat di kawasan Taluak buo ini menggunakannya sebagai obat sakit perut dan panas dalam. Bagian tumbuhan yang digunakan adalah daun, bunga dan buahnya (Rizki \& Leilani, 2017). Di daerah Pariaman tumbuhan mangrove ini juga digunakan sebagai bahan obat-obatan yang dapat menyembuhkan berbagai penyakit (Milda, Leilani \& Rizki, 2012).

$R$. apiculata dapat tumbuh pada tanah yang berlumpur halus, dan tergenang pada saat pasang normal. $R$. apiculata merupakan salah satu jenis tumbuhan yang paling mendominasi pada satu daerah tertentu atau homogen. $R$. apiculata memiliki struktur pohon yang dapat mencapai tinggi $30 \mathrm{~m}$, dengan diameter mencapai $50 \mathrm{~cm}$ (Setiawan, 2008). Menurut Tjitrosoepomo (2007), Rhizophora apiculata, di klasifikasikan sebagai berikut: Kingdom: Plantae, Divisio: Spermatophyta, Subdivisio: Angiospermae, Classis: Dicotyledonae, Subclass: Dialypetalae, Ordo: Myrtales, Familia: Rhizophoraceae, Genus: Rhizophora, Species: Rhizophora apiculata.

Pada penelitian Ritawati (2001) tentang komposisi dan zonasi hutan mangrove Taluak Buo, diketahui bahwa Rhizophora apiculata mendominasi kawasan hutan mangrove tersebut. namun belum diketahui bagaimana populasi dari species $R$. apiculata ini, berdasarkan hal tersebut penulis telah melakukan penelitian yang berjudul srtuktur populasi $R$. apiculata di hutan mangrove Taluak Buo Kecamatan Bungus Teluk Kabung Kota Padang. 


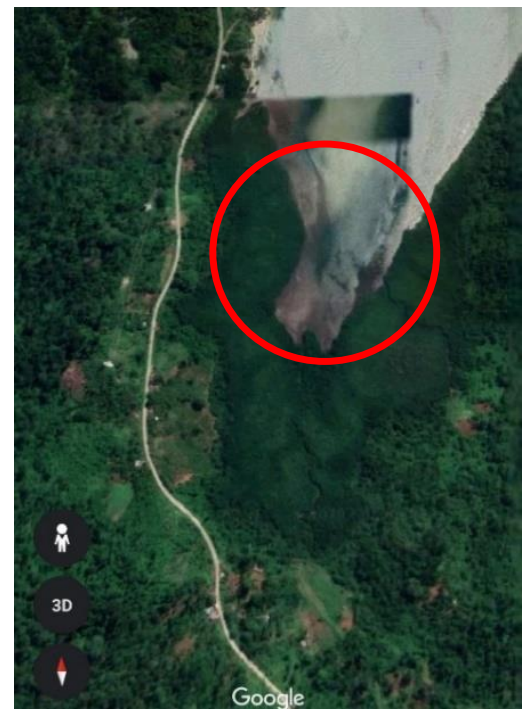

a

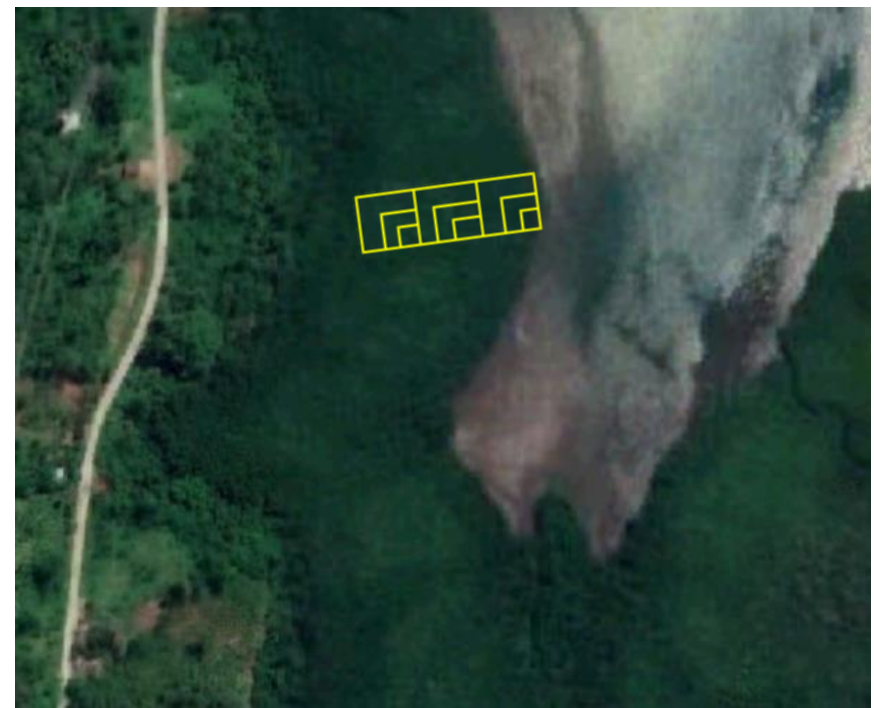

b

Gambar 1. Citra satelit kondisi mangrove Taluak Buo a. Area pengambilan sampel, b. Plot penelitian

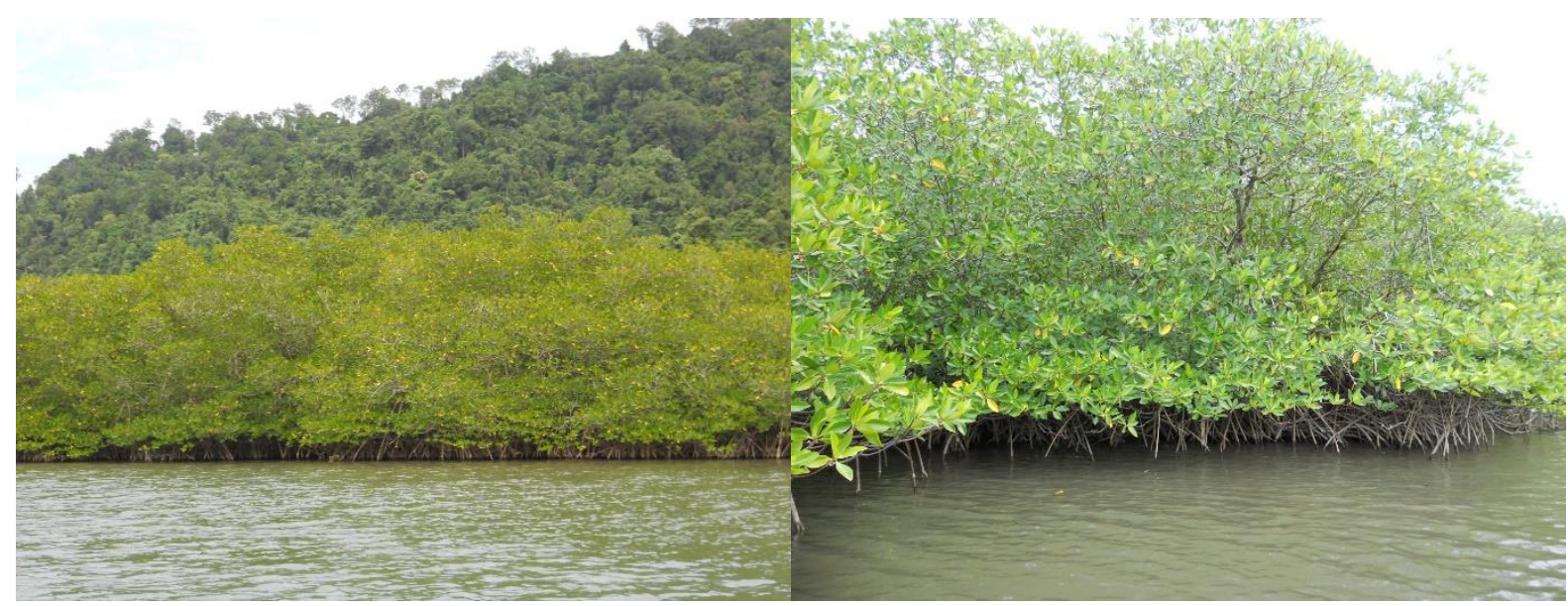

Gambar 2 . Kondisi Hutan Mangrove Teluk Buo Padang

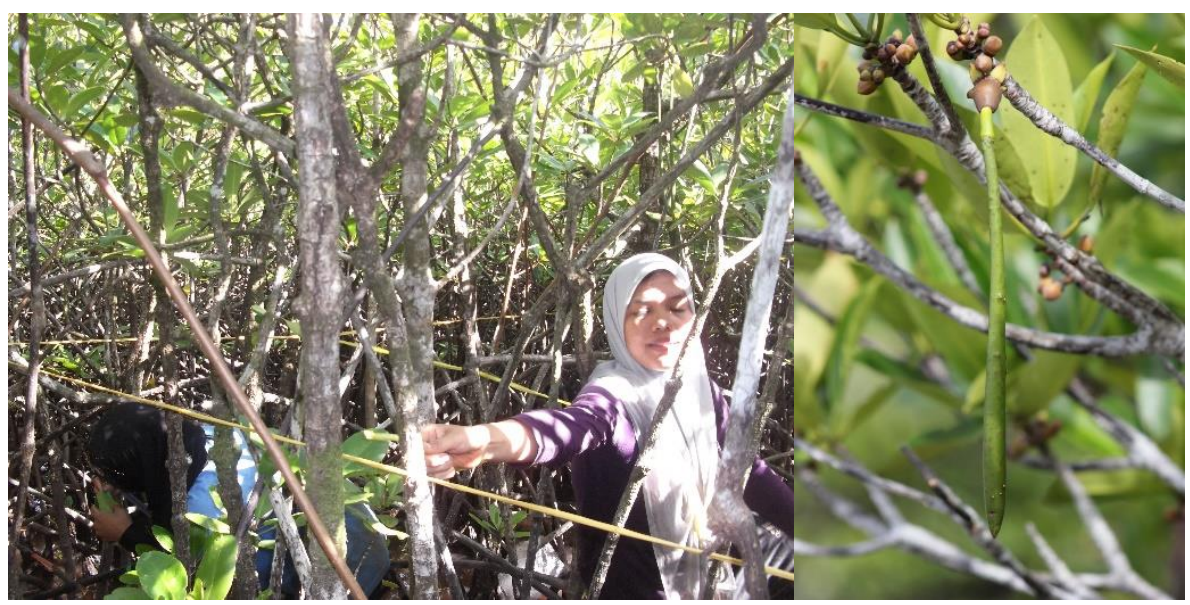

Gambar 3. Morfologi R. apiculata 
Taluak Buo adalah daerah yang berada di kelurahan Teluk Kabung Tengah. Batas wilayah Taluak Buo sebelah utara berbatasan dengan laut Teluk Kabung, sebelah selatan dengan kelurahan Sungai Pisang, sebelah barat dengan Samudra Indonesia, dan sebelah timur dengan kelurahan Teluk Kabung. Taluak buo berada di RW 4, RT 1 Teluk Kabung Tengah dengan luas wilayah 2562 ha. Kawasan ini masih termasuk pada daratan pesisir kota Padang dimana pada lokasi ini mempunyai potensi mangrove yang cukup luas dan padat yaitu 10 ha. Substrat yang terdapat di Teluk Buo terdiri dari lumpur, pasir, berkarang dan lumpur berpasir. Daerah Taluak Buo dihuni oleh 53 KK yang merupakan bagian dari Kelurahan Teluk Kabung Tengah. Transportasi menuju daerah ini dulunya hanya bisa dengan menggunakan jalur laut tapi sejak tahun 2007 sampai sekarang warga sekitar telah bisa menggunakan jalur darat, hal ini dikarenakan karna di kawasan tersebut sedang dibangun pembangkit listrik tenaga uap (PLTU).

\section{METODE PENELITIAN}

Alat-alat yang digunakan dalam penelitian ini adalah: meteran, parang, cutter atau gunting, camera digital, dan alat tulis sedangkan bahan yang digunakan adalah: Rhizophora apiculata, tali raffia. Sebelum dilaksanakannya penelitian, terlebih dahulu dilaksanakan survey ke lapangan yang merupakan studi pendahuluan unuk mendapatkan gambaran umum mengenai vegetasi mangrove dan lingkungannya, selanjutnya dilakukan pembuatan garis rintisan yang berfungsi sebagai garis transek.

Garis transek ini dimulai dari bibir pantai sampai ke zona transisi hutan mangrove, setelah garis transek dibuat maka selanjutnya dilakukan pembuatan plot berukuran 10x10m untuk pohon, kemudian untuk anakan di buat plot 5x5m, dan terakhir untuk menghitung semai di buat plot 1 x 1m (Indriyanto, 2006). Plot anakan, dan semai dibuat secara selang-seling di kiri-kanan pada plot pohon 10x10 m. Setelah selesai dilakukan penghitungan data, data yang diambil adalah jumlah individu dan lingkar diameter batang setinggi dada pada masing- masing pohon, anakan, dan semai. Pohon adalah individu dengan diameter $>10 \mathrm{~cm}$, anakan adalah individu dengan tinggi $>1,5 \mathrm{~m}$ dan diameter $<10 \mathrm{~cm}$, dan untuk semai adalah individu dengan $<1,5 \mathrm{~m}$ (Kusmana 1997). 


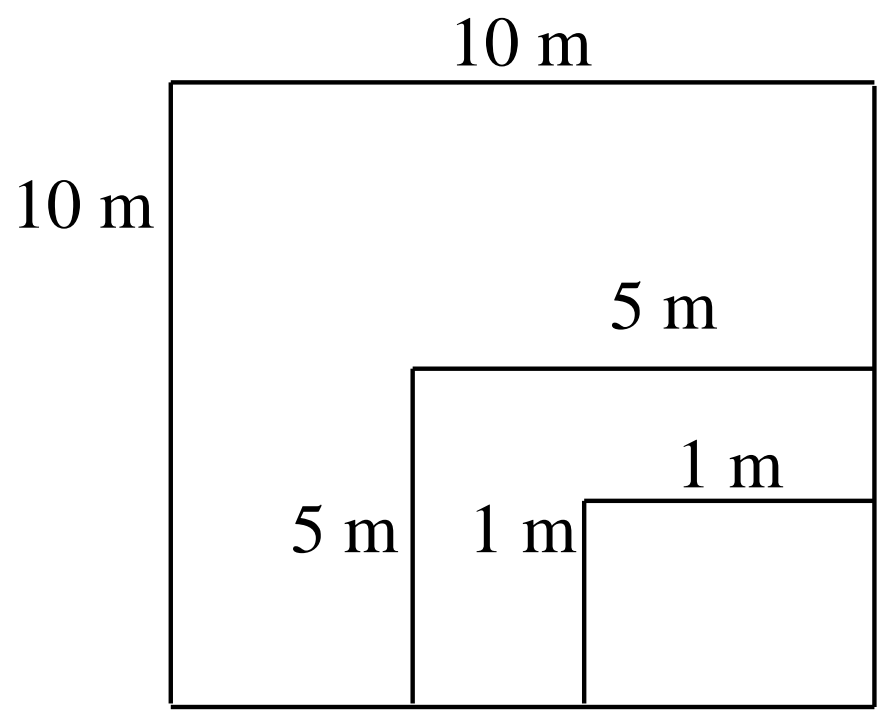

Gambar 4. Contoh Plot Penelitian 10x10 pohon, 5x5 sapling, 1x1 seedling

Teknik analisis data yang digunakan adalah data deskriptif. Data yang didapatkan dari hasil observasi di lapangan, dimana diperoleh dari lapangan kemudian dihitung dengan menggunakan:

1. Kerapatan $\left(\frac{\text { ind }}{\mathrm{m}^{2}}\right)=\frac{\text { Jumlah Individu Suatu Jenis }}{\text { Luas Seluruh Plot }}$

2. Dominansi $\left(\frac{\mathrm{m}^{2}}{\mathrm{ha}}\right)=\frac{\text { Jumlah Basal Area Suatu Jenis }}{\text { Luas Seluruh Plot }}$

(Indriyanto, 2006)

\section{HASIL DAN PEMBAHASAN}

Tabel 1. Hasil Kerapatan dan Dominansi Rhizophora apiculata di hutan mangrove Taluak Buo.

\begin{tabular}{llllll}
\hline & \multicolumn{2}{c}{ Kerapatan $\left(\mathrm{ind} / \mathrm{m}^{2}\right)$} & \multicolumn{2}{c}{ Dominansi $\left(\mathrm{m}^{2}\right)$} \\
\hline Pohon & Anakan & Semai & Pohon & Anakan & Semai \\
0,161 & 0,773 & 2,133 & 0,000381 & 0,000593 & 0,0000943
\end{tabular}




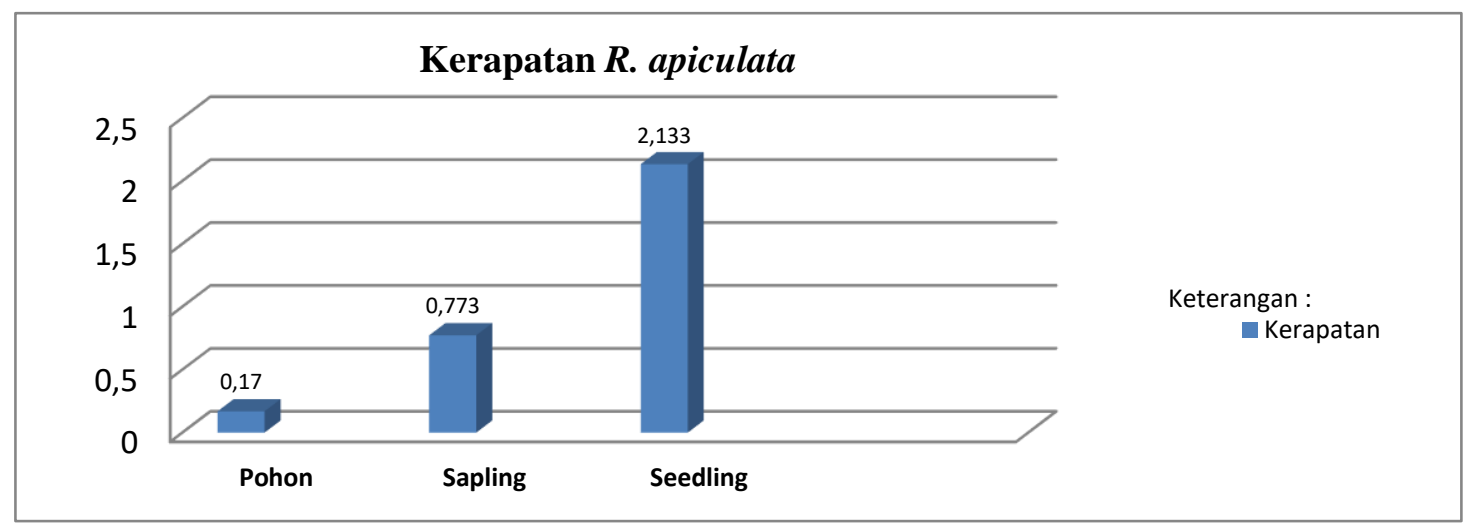

Gambar 5. Kerapatan R. apiculata

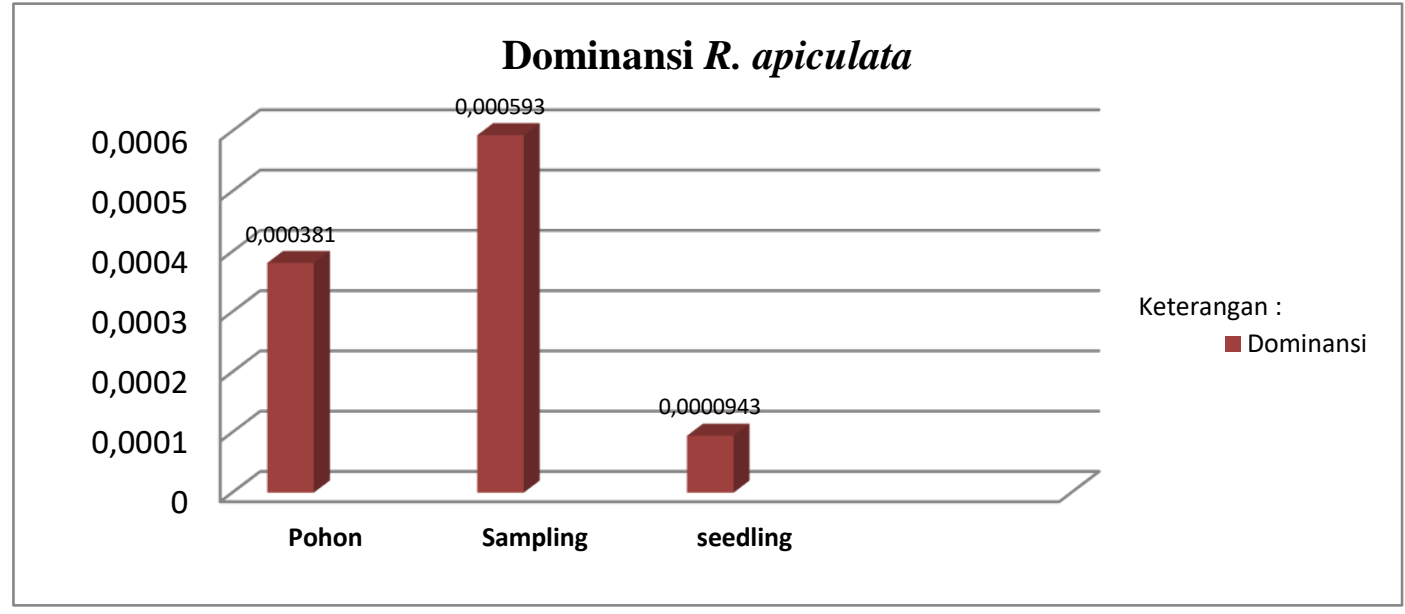

Gambar 6. Dominansi R. apiculata

Tabel 2. Hasil Pengukuran Faktor Lingkungan

\begin{tabular}{cll}
\hline No & \multicolumn{1}{c}{ Parameter } & \multicolumn{1}{c}{ Nilai } \\
\hline 1 & Suhu & $29,3-28,7{ }^{0} \mathrm{C}$ \\
2 & Kecerahan & $30 \mathrm{~cm}$ (pasang) \\
3 & Salinitas & $27 \% 00$ \\
5 & Ketinggian Pasang & $40-96 \mathrm{~cm}$ \\
6 & Oksigen Terlarut & $5,43-5,48 \mathrm{mg} / \mathrm{L}$ \\
\hline
\end{tabular}

Kerapatan Rhizophora apiculata di hutan mangrove Taluak Buo tertinggi ada pada tingkat pertumbuhan semai $2,133 \mathrm{ind} / \mathrm{m}^{2}$. Jika di bandingkan dengan hasil penelitian Tambunan (2009) di kabupaten Deli Serdang Bedagai, kerapatan $R$. apiculata pada tingkat semai yaitu $0,0802 \mathrm{ind} / \mathrm{m}^{2}$. Hal ini menunjukkan bahwa hutan mangrove Taluak Buo memiliki kerapatan semai lebih besar dari kerapatan di kabupaten Deli Serdang Bedagai, bila di 
bandingkan dengan penelitian Ritawati kerapatan semai di Taluak Buo yaitu 0, $1700 \mathrm{ind} / \mathrm{m}^{2}$, jadi terdapat kenaikan terata jumlah individu semai sebasar 1, $963 \mathrm{ind} / \mathrm{m}^{2}$ dalam 12 tahun.

Kerapatan anakan $R$. apiculata adalah 0,773 ind $/ \mathrm{m}^{2}$. Jika dibandingkan dengan hasil penelitian yang dilakukan oleh Ritawati (2001), kerapatan $R$. apiculata pada tingkat anakan yaitu $0,0708 \mathrm{ind} / \mathrm{m}^{2}$, dan penelitian Tambunan (2009) di Deli Serdang 0,0226 ind $/ \mathrm{m}^{2}$. Hasil tersebut dapat terlihat bahwa $R$. apiculata pada hutan mangrove Taluak Buo sedang mangalami pertumbuhan yang cukup bagus dengan jumlah inidvidu anakan lebih banyak dari 2 penelitian sebelumnya. Pertumbuhan seedling menjadi sapling sering terjadi gangguan seperti terbawa arus gelombang laut, dimakan kepiting dan hewan lainnya. Untuk meningkatkan kesintasan hidup anakan mangrove ini perlu dilakukan pembibitan mangrove dengan memanfaatkan tanah topsoil (Rizki \& Novi, 2017)

Pada tingkatan pohon Kerapatan $R$. apiculata yaitu 0, $161 \mathrm{ind} / \mathrm{m}^{2}$. Menurut hasil penelitian Ritawati (2001) kerapatan pohon $R$. apiculata $0,0440 \mathrm{ind} / \mathrm{m}^{2}$, bila dibandingkan dengan hasil penelitian Tambunan (2008) yaitu 0,0009 ind $/ \mathrm{m}^{2}$. Maka dalam hal ini terlihat bahwa jumlah individu pohon $R$. apiculata Taluak Buo lebih banyak. Adanya pertumbuhan yang baik pada tumbuhan $R$. apiculata tingkat pohon pada hutan mangrove Taluak Buo, menjadi bukti bahwa dengan demikian banyak pohon yang berhasil tumbuh dengan baik yang nantinya akan menghasilkan propagul $R$. apiculata dan tumbuh menjadi semai. Pertumbuhan pohon $R$. apiculata tersebut juga di dukung oleh faktor lingkungan di kawasan hutan mangrove Taluak Buo tersebut.

Pada hutan mangrove Taluak Buo diketahui dominansi tertinggi ada pada anakan 0 , $000593 \mathrm{~m}^{2}$ selanjutnya $0,000381 \mathrm{~m}^{2}$ pada pohon dan $0,0000943 \mathrm{~m}^{2}$ pada semai. Tingginya dominansi anakan di hutan mangrove Taluak Buo menjadikan hutan mangrove sebagai hutan yang masih muda karena masih memiliki tingkat penguasaan bidang dasar cukup besar. Pertumbuhan dan perkembangan suatu vegetasi mangrove juga di dukung oleh faktor lingkungannya. Faktor lingkungan memiliki peranan penting dalam pertumbuhan dan perkembangan $R$. apiculata di kawasan hutan mangrove Taluk Buo.

Pertumbuhan dan perkembangan suatu vegetasi mangrove juga di dukung oleh faktor lingkungannya. Faktor lingkungan memiliki peranan penting dalam pertumbuhan dan perkembangan $R$. apiculata di kawasan hutan mangrove Taluk Buo. Berdasarkan data yang telah di peroleh pada saat pengukuran faktor lingkungan di kawasan hutan mangrove Taluak Buo di ketahui bahwa kawasan mangrove Taluak Buo umumnya masih memenuhi syarat untuk kehidupan vegetasi mangrove. 
Suhu mempunyai pengaruh kritis terhadap proses esensial tumbuhan seperti fotosintesis, respirasi dan respirasi pada akar, karena suhu yang terlalu tinggi akan meningkatkan penguapan air dari tumbuhan. Suhu antara $30-48^{\circ} \mathrm{C}$ merupakan kondisi yang baik untuk pembentukan klorofil pada kebanyakan tumbuhan, akan tetapi yang paling baik dan optimum adalah anatar 26- $30^{\circ} \mathrm{C}$ (Purnobasuki, 2005). Selama penelitian didapatkan suhu antara waktu pasang dan surut yaitu 29, 3-28,70 C. Suhu ini sangat cocok untuk pertumbuhan R. apiculata di hutan mangrove Taluak Buo.

Hasil pengukuran kecerahan peraiaran di Taluak Buo pada saat pasang yaitu $30 \mathrm{~cm}$, pada saat surut tidak dapat dilakukan pengukuran kecerahan karena sinar matahari langsung menembus dasar perairan, hal ini disebabkan karena jumlah air yang sedikit. Dari hasil tersebut dapat di ketahui bahwa pada hutan mangrove Taluak Buo kecerahannya cukup bagus.

Salinitas atau kadar garam mempunyai peranan penting sebagai faktor penentu dalam pertumbuhan. Salinitas yang didapatkan pada saat penelitian pada pasang dan surut yaitu $27 \%$, kisaran ini cukup baik bagi kawasan mangrove.

Hasil pengamatan pasang dan surut pada hutan mangrove Taluak Buo yaitu pada saat pasang mencapai ketinggian 40- $96 \mathrm{~cm}$, dan pada saat surut 0- $30 \mathrm{~cm}$. Pasang tertinggi terjadi pada siang hari. Pornubasuki (2005), menyatakan bahwa Pasang surut air laut mempunyai pengaruh terhadap pertumbuhan dan produktivitas mangrove antara lain, pasang surut menentukan pangangkutan oksigen ke sistem akar, pembasuhan air pasang memengaruhi erosi dan kandungan garam pada air tanah

Oksigen merupakan gas terpenting bagi semua makhluk hidup dan tidak terkecuali pada tumbuhan. Perubahan oksigen terlarut di suatu lingkungan sangat berpengaruh terhadap organisme, kebutuhan oksigen pada suatu organisme sangat bervariasi. Oksigen terlarut yang didapatkan pada kawasan hutan mangrove Taluak Buo pada waktu pasang dan surut yaitu 5, 43- 5, $48 \mathrm{mg} / \mathrm{L}$.

Berdasarkan data yang telah di peroleh pada saat pengukuran faktor lingkungan di kawasan hutan mangrove Taluak Buo di ketahui bahwa kawasan mangrove Taluak Buo umumnya masih dalam keadaan alami. Dari hasil penelitian tersebut dapat disimpulkan bahwa hutan mangrove Taluak Buo disusun oleh komunitas muda yang berkembang dengan baik, hal ini sesuai dengan pendapat Machmudh dalam Ritawati (2001) bahwa hutan mangrove yang disusun oleh komunitas muda merupakan hutan yang memiliki keseragaman dan didominasi oleh Rhizophoraceae yang masih muda. 


\section{KESIMPULAN}

Kerapatan Rhizophora apiculata tertinggi ada pada tingkat semai 2,133 ind $/ \mathrm{m}^{2}$, selanjutnya tingkat anakan $0,773 \mathrm{ind} / \mathrm{m}^{2}$, dan terakhir tingkat pohon $0,161 \mathrm{ind} . / \mathrm{m}^{2}$.Dominansi Rhizophora apiculata tertinggi ada pada tingkat anakan $0,000593 \mathrm{~m}^{2}$ selanjutnya pada tingkat pohon $0,000381 \mathrm{~m}^{2}$, dan terakhir pada tingkat semai $0,0000943 \mathrm{~m}^{2}$.

\section{DAFTAR PUSTAKA}

Abdullah, 1984. Pelestarian dan Peranan Hutan Mangrove di Indonesia dalam Prosiding Seminar II Ekosistem Mangrove Proyek Lingkungan Hidup- LIPI: Jakarta.

Dahuri. 2003. Keanekaragaman Hayati Laut Aset Pembangunan berkelanjutan Indonesia. PT. Gramedia Pustaka Utama: Jakarta.

Indriyanto. 2006. Ekologi Hutan. PT. Bumi Aksara: Jakarta

Kusmana, C. 1997. Metode Survey Vegetasi. PT. Penerbit IPB: Bandung.

Milda, T., \& Leilani, I. (2012). STUDI ETNOBOTANI PADA HUTAN MANGROVE DI KENAGARIAN MANGGUANG KOTA PARIAMAN. e-Jurnal Mahasiswa Prodi Pend Biologi 2012, 1(1).

Purnobasuki, H. 2005. Tinjauan Persepektif Hutan Mangrove. Universitas Airlangga: Surabaya.

Ritawati. 2001. Komposisi dan Zonasi Hutan Mangrove di Teluk Buo, Padang. Skripsi Jurusan Biologi FMIPA Universitas Andalas: Padang.

Rizki, R., \& Leilani, I. (2018). Etnofarmakologi Tumbuhan Familia Rhizophoraceae oleh Masyarakat di Indonesia. Jurnal Bioconcetta, 3(1).

Rizki, R., \& Novi, N. (2017). Respon Pertumbuhan Bibit Mangrove Rhizophora Apiculata B1 pada Media Tanah Topsoil. Jurnal Bioconcetta, 3(2).

Rizki, R., Safitri, E., \& Asroen, A. (2016). Morfologi Bruguiera Cylindrica (L.) Blume Yang Tumbuh Di Hutan Mangrove Kecamatan Siberut Utara Kabupaten Kepulauan Mentawai. Sainstek: Jurnal Sains dan Teknologi, 7(1), 26-32.

Setiawan, D. A, Ari S. W dan Sutarno. 2008. Biodiversitas Ekosisitem Mangrove di Jawa. UNS: Surakarta.

Tambunan, P. 2009. Kajian Potensi Ekonomi Mangrove. Skripsi. Fakultas Pertanian. Universitas Sumatera Utara : Medan

Tarigan, M. S. 2008. Sebaran dan Luas Hutan Mangrove di Wilayah Pesisir Teluk Pising Utara Pulau Kabaena Provinsi Sulawesi Tenggara, (online). Jurnal Makara, Sains. Jakarta: Pusat Penelitian Oseanografi. LIPI. Diakses 4 Agustus 2011.

Tjitrosoepomo. G. 2007. Taksonomi Tumbuhan. Gajah Mada University Press: Yogakarta

The Plant List (2013). Version 1.1. Published on the internet;http://www.theplantlist.org (accessed 2019, 1st September) 